\title{
A Theoretical HSAB Study of the Acidity of Carbon Acids $\mathrm{CH}_{3} \mathrm{Z}$
}

\author{
Marcos C. Rezende \\ Facultad de Química y Biología, Universidad de Santiago, Casilla 40, Correo 33, Santiago, Chile
}

\begin{abstract}
A acidez em fase gasosa de nove ácidos carbonados do tipo $\mathrm{CH}_{3} \mathrm{Z}$ (nitrometano, acetofenona, dimetilsulfona, acetaldeído, butanona, acetona, acetato de metila, acetonitrila e dimetilsulfóxido ) foi estudada, em busca de correlações com propriedades locais e globais, calculadas em níveis 321G, 6-31G* e 6-31+G(3df,2p), segundo a teoria de ácidos e bases duros e macios ("HSAB"). Uma correlação razoável foi obtida com as energias de deprotonação calculadas, o que permitiu estimar a acidez em fase gasosa do tioacetato de metila $\left(\Delta \mathrm{G}^{\mathrm{o}}=1476 \mathrm{~kJ} \mathrm{~mol}^{-1}\right)$, próxima da do nitrometano, o membro mais ácido da série. As funções de Fukui para ataque nucleofílico dos centros aniônicos duros e macios em cada base ${ }^{-} \mathrm{CH}_{2} \mathrm{Z}$ foram usadas para interpretar as variações de acidez quando os ácidos são transferidos da fase gasosa para a fase aquosa.
\end{abstract}

The gas-phase acidity of nine carbon acids of the form $\mathrm{CH}_{3} \mathrm{Z}$ (nitromethane, acetophenone, dimethylsulfone, acetaldehyde, butanone, acetone, methyl acetate, acetonitrile and dimethylsulfoxide) was investigated, in the search of correlations with global and local HSAB properties, calculated at the $3-21 \mathrm{G}, 6-31 \mathrm{G}^{*}$ and $6-31+\mathrm{G}(3 \mathrm{df}, 2 \mathrm{p})$ levels. A reasonable correlation was obtained with the calculated ionization energies. Based on the obtained correlation, the gasphase acidity of methyl thioacetate was estimated $\left(\Delta \mathrm{G}^{0}=1476 \mathrm{~kJ} \mathrm{~mol}^{-1}\right)$ as close to that of the most acidic member of the series, nitromethane. The nucleophilic Fukui functions of the hard and soft anionic centers in each base ${ }^{-} \mathrm{CH}_{2} \mathrm{Z}$ stabilized by direct conjugation were calculated, following two different approaches, and their ratios utilized to interpret the shifts in acidity when the acids are transferred from gas-phase to aqueous solution.

Keywords: acidity, carbon acids, HSAB theory, Fukui functions

\section{Introduction}

DFT-based HSAB theory provides the chemist with a variety of descriptors that have been successfully correlated with properties such as acidity / basicity and reactivity of organic molecules.

Since the original definition of these descriptors ${ }^{1-3}$ the theory has been tested with a variety of properties. Examples include the gas-phase basicity of amines ${ }^{4,5}$, the calculation of electronegativities and hardness values for substituents ${ }^{6}$, the acidity of alcohols ${ }^{7}$, of substituted acetic acids ${ }^{8}$ and phenols ${ }^{9}$. An example of the prediction of the unknown acidities of a family of compounds is provided by the calculation of $\mathrm{pK}_{\mathrm{a}}$ values of hydrofullerenes, based on correlations with various organic acids ${ }^{10}$.

This potential use of theoretical tools is particularly interesting in those cases where a direct measurement of a given property poses experimental difficulties, even in the

e-mail:mcaroli@lauca.usach.cl case of simple systems. As an example, measurements of the basicity of ester carbanions in water have been traditionally restricted to those few stable species, capable of appreciable ionization in relatively weak basic solutions. The concomitant basic hydrolysis of simple esters had traditionally made the determination of their $\mathrm{pK}_{\mathrm{a}}$ values in water a particularly difficult task ${ }^{11}$. As a result, direct measurements of the acidity of fairly simple esters like ethyl acetate $^{12}$ or thioacetate ${ }^{13}$ have been reported only recently.

These considerations led us to investigate theoretically the acidity of a series of carbon acids of the form $\mathrm{CH}_{3} \mathrm{Z}$, where $\mathrm{Z}$ is a carbanion-stabilizing group, utilizing concepts derived from the HSAB theory. The compounds studied in this work belong to a family of carbon acids that span a wide range (ca. $20 \mathrm{pK}_{\mathrm{a}}$ units) of acidity values in solution. An interesting feature of the series, which is absent in other families like alcohols, phenols or carboxylic acids, is the presence in all molecules of at least one hard center, in addition to the soft $\mathrm{C}$ atom of the derived carbanions. This suggested the search of possible correlations in terms of local HSAB properties, to be compared with experimental 
data, like their behaviour in gas phase and in solution. The acidity of the studied compounds changes significantly from the gas phase to aqueous solutions. Although the HSAB descriptors obtained theoretically should apply to the gas-phase acid behaviour, an attempt was made to interpret their changes in acidity on being transferred to water, by means of local descriptors like the Fukui function.

\section{Results and Discussion}

The global HSAB descriptors employed in this work comprised the electronegativity $\chi$, the chemical potential $\mu=-\chi$, the hardness $\eta$ and the softness $S=1 / \eta$ of the systems. Their calculation utilized Koopman's approximation, equations (1) and (2)

$\mu=-\chi=\left(\varepsilon_{\mathrm{L}}+\varepsilon_{\mathrm{H}}\right) / 2$

$\eta=1 / S=\left(\varepsilon_{L}-\varepsilon_{H}\right) / 2$

where $\varepsilon_{\mathrm{L}}$ and $\varepsilon_{\mathrm{H}}$ are the LUMO and the HOMO eigenvalues, respectively ${ }^{1-3,9}$.

Local descriptors included the local softness $\mathrm{s}_{\mathrm{k}}{ }^{-}$and the Fukui function for nucleophilic attack $\mathrm{f}_{\mathrm{k}}{ }^{-}$of chosen atoms. The former is simply the product of the global softness $\mathrm{S}$ by $\mathrm{f}_{\mathrm{k}}{ }^{-}$at a given site $\mathrm{k}$.

$\mathrm{s}_{\mathrm{k}}{ }^{-}=\mathrm{S} \cdot \mathrm{f}_{\mathrm{k}}^{-}$

For the calculation of the Fukui function we employed two different approaches. The first of them, proposed by Yang and Mortier ${ }^{4}$, utilizes the gross Mulliken charge at site $\mathrm{k}, \mathrm{q}_{\mathrm{k}}$, for systems with $\mathrm{N}$ and $\mathrm{N}-1$ electrons, calculated at the same geometry 9 .

$\left(\mathrm{f}_{\mathrm{k}}^{-}\right)_{1}=\mathrm{q}_{\mathrm{k}}(\mathrm{N})-\mathrm{q}_{\mathrm{k}}(\mathrm{N}-1)$

This approach has been recently criticized, as prone to computational convergence troubles, and an equivalent treatment has been put forward, with the advantage that only one single-point calculation is required ${ }^{5}$. This second method thus avoids the inevitable change of multiplicity of the electronic state of the first method. The Fukui function for nucleophilic attack, $\left(\mathrm{f}_{\mathrm{k}}{ }^{-}\right)_{2}$, may be calculated by the sum of two terms, as defined in (5).

$$
\left(\mathrm{f}_{\mathrm{k}}^{-}\right)_{2}=\sum_{\mu \in \mathrm{k}}\left|\mathrm{c}_{\mu \mathrm{h}}\right|^{2}+\sum_{\mu \in \mathrm{k}} \sum_{v \neq \mu} \mathrm{c}_{\mu \mathrm{h}} \mathrm{c}_{v \mathrm{~h}} \mathrm{~S}_{\mu \nu}
$$

The first term in (5) is the sum of the squared atomicorbital coefficients of atom $\mathrm{k}$ in the HOMO. The second term involves products of the HOMO coefficients of atom $\mathrm{k}$ with all other atoms, and the overlap integrals $S_{\mu \nu}$ between the corresponding basis functions. It is seen that this definition of the Fukui function for nucleophilic attack is simply the overall HOMO density at site $\mathrm{k}$, partitioned into a first term, which is the density at the atom, and a second term, which is the electronic density shared with the rest of the molecule. Unfortunately, the second term, unlike the first one, is not directly obtained from the Gaussian output, but must be calculated by means of a short routine added to the MulPop link 601 of the program ${ }^{5}$. This limitation may be partly circumvented by considering the relative weight of the two terms in the sum (5). In a study of seven alkylamines, the contribution of the second term amounted to only 5 $9 \%$ of the sum, and was found to be roughly constant ${ }^{5}$. As a result, the same correlation coefficient $(r=0.995)$ was obtained when the exact Fukui function, calculated by (5), and the approximate function, derived from (6)

$\left(\mathrm{f}_{\mathrm{k}}^{-}\right)_{2} \approx \sum_{\mu \in \mathrm{k}}\left|\mathrm{c}_{\mu \mathrm{h}}\right|^{2}$

were plotted against the amine gas-phase basicities.

These observations led to the utilization in this work of the approximation (6), for the calculation of $\left(\mathrm{f}_{\mathrm{k}}{ }^{-}\right)_{2}$.

The two approaches presented above may be summarized in qualitative terms. According to the approach of Yang and Mortier ${ }^{4}$, the Fukui function for nucleophilic attack, $\left(\mathrm{f}_{\mathrm{C}^{-}}{ }_{1}\right.$, is defined as a measure of the tendency, by a given atom, to give away its share of one electron. In the gas-phase, this is also a measure of the basicity of a given atom. In an alternative, equivalent approach, Contreras et $a l . .^{5}$ defined the Fukui function $\left(\mathrm{f}_{\mathrm{C}^{-}}\right)_{2}$ as the total HOMO density of a given atom, partitioned into a sum of two terms, the HOMO density at the atom itself and the density shared by its overlap with other atoms in the molecule. The second term is neglected in the present paper, based on the fact that it amounts to $5-9 \%$ of the total density, and is roughly constant for a series of analogous compounds 5 .

All calculations were performed with a Gaussian 94w program ${ }^{14}$. Optimizations of the structures of the investigated carbon acids and their corresponding anions were carried out at an HF/3-21G level, after being initially optimized via the semiempirical AM1 method. This level of calculation had proved successful in the theoretical treatment of the acidity of substituted acetic acids ${ }^{8}$, phenols $^{9}$ and hydrofullerenes ${ }^{10}$. Calculations of amine basicities employing a smaller basis set (HF/ STO-3G) yielded results which were as good, and even superior to those obtained with larger basis sets $\left(6-31 \mathrm{G} \text { and } 6-311 \mathrm{G}^{* *}\right)^{5}$, suggesting that there was no need of resorting to more costly methods in the present calculations. Nevertheless, this assumption was checked in the present work, by performing in addition single-point calculations at the 6-31G* and 6-31+G (3df,2p) levels, on the structures optimized with the $3-21 \mathrm{G}$ basis set. 
The decision as to the conformations to be considered in the calculations was in most cases straightforward. In the case of methyl acetate and butanone, the structures with the methyl groups syn to the carbonyl oxygen were chosen as the most stable conformations ${ }^{15}$.

In Table 1 are listed literature values for the acidity of nine carbon acids $\mathrm{CH}_{3} \mathrm{Z}\left(\mathrm{Z}=\mathrm{NO}_{2}, \mathrm{COPh}, \mathrm{SO}_{2} \mathrm{Me}, \mathrm{COH}\right.$, $\mathrm{COEt}, \mathrm{COMe}, \mathrm{CO}_{2} \mathrm{Me}, \mathrm{CN}$ and $\mathrm{SOMe}$ ) in the gas phase and in solution (DMSO and water). Acidity values in the gas phase are expressed as free-energy values of ionization, $\Delta \mathrm{G}^{\mathrm{o}}\left(\mathrm{kJ} \mathrm{mol}^{-1}\right)$, acidities in solution in $\mathrm{pK}_{\mathrm{a}}$ values. Most free-energy values of ionization in the gas phase are quoted directly ${ }^{16}$, or were obtained by simple manipulation of data from literature ${ }^{17-19}$. The reported $\Delta \mathrm{G}^{\mathrm{o}}$ value for butanone was obtained by interpolation, with the aid of a relationship between $\Delta \mathrm{G}^{\mathrm{o}}$ and $\Delta \mathrm{H}^{\mathrm{o}},\left[\Delta \mathrm{G}^{\mathrm{o}}=1328.33+0.7866 \Delta \mathrm{H}^{\mathrm{o}}\right.$, $\mathrm{r}=0.999]$ derived from data for six compounds, and an enthalpy value of $229 \mathrm{~kJ} \mathrm{~mol}^{-1}$, from the same source ${ }^{16}$. The $\mathrm{pK}_{\mathrm{a}}$ value of methyl acetate in water was assumed equal to the value of the $\mathrm{pK}_{\mathrm{a}}$ value of ethyl acetate ${ }^{12}$.

Table 1. Acidity of nine carbon acids $\mathrm{CH}_{3} \mathrm{Z}$ in the gas phase and in solution.

\begin{tabular}{llccc}
\hline & & $\Delta \mathrm{G}^{\circ} / \mathrm{kJ} \mathrm{mol}^{-1}$ & \multicolumn{2}{c}{$\mathrm{pK}_{\mathrm{a}}$ Value } \\
\hline & $\mathrm{Compound}$ & Gas Phase & DMSO & Water \\
\hline (1) & $\mathrm{CH}_{3} \mathrm{NO}_{2}$ & $1473^{\mathrm{a}}$ & $17.2^{\mathrm{b}}$ & $10.2^{\mathrm{c}}$ \\
(2) & $\mathrm{CH}_{3} \mathrm{COPh}$ & $1491^{\mathrm{a}}$ & $24.7^{\mathrm{b}}$ & $19.5^{\mathrm{c}}, 18.3^{\mathrm{d}}$ \\
(3) & $\mathrm{CH}_{3} \mathrm{SO}_{2} \mathrm{Me}$ & $1502^{\mathrm{a}}$ & $31.1^{\mathrm{b}}$ & $28.5^{\mathrm{c}}$ \\
(4) & $\mathrm{CH}_{3} \mathrm{CHO}$ & $1504^{\mathrm{a}}$ & - & $16.7^{\mathrm{d}}$ \\
(5) & $\mathrm{CH}_{3} \mathrm{COEt}$ & $(150)^{\mathrm{e}}$ & $24.4^{\mathrm{b}}$ & - \\
(6) & $\mathrm{CH}_{3} \mathrm{COMe}$ & $1513^{\mathrm{f}}$ & $26.5^{\mathrm{b}}$ & $19.3^{\mathrm{d}}$ \\
(7) & $\mathrm{CH}_{3} \mathrm{CO} \mathrm{Me}$ & $1513^{\mathrm{a}}$ & - & $(25.6)^{\mathrm{g}}$ \\
(8) & $\mathrm{CH}_{3} \mathrm{CN}$ & $1524^{\mathrm{a}}$ & $31.3^{\mathrm{b}}$ & $25.0^{\mathrm{c}}$ \\
(9) & $\mathrm{CH}_{3} \mathrm{SOMe}$ & $1530^{\mathrm{a}}$ & $35.0^{\mathrm{b}}$ & $28.5^{\mathrm{c}}$ \\
\hline
\end{tabular}

(a) From ref. 16, p. 227; (b) From ref. 17; (c) From ref. 16, p. 220; (d) From ref. 12; (e) From ref 16, p. 226; obtained by interpolation from the relationship between $\Delta \mathrm{H}^{\mathrm{o}}$ and $\Delta \mathrm{G}^{\mathrm{o}}$ values for six compounds, $\Delta \mathrm{G}^{\mathrm{o}}=1328.33+0.7866 \Delta \mathrm{H}^{\mathrm{o}}$, with a correlation coefficient $\mathrm{r}=0.999$ and an enthalpy value of $229 \mathrm{~kJ} \mathrm{~mol}^{-1}$; (f) From ref. 19; (g) Value assumed equal to that of ethyl acetate taken from reference 12 .
Compounds are listed in order of decreasing acidity in the gas phase. As can be gathered from inspection of Table 1, this order is not followed in solution.

A first test of correlation of theoretical parameters with the experimental data was performed with the deprotonation energies $\Delta \mathrm{E}$ of the nine carbon acids. This term is the difference between the total energy of the conjugate base $\mathrm{E}\left(\mathrm{A}^{-}\right)$and that of its acidic form $\mathrm{E}(\mathrm{AH})^{10}$.

$\Delta \mathrm{E}=\mathrm{E}\left(\mathrm{A}^{-}\right)-\mathrm{E}(\mathrm{AH})$

A very good correlation $(r=0.994)$ had been obtained for a series of seven carbon acids, with a range of $\mathrm{pK}_{\mathrm{a}}$ values spanning almost 50 units, when their acidity values in DMSO were plotted against the corresponding deprotonation energies $\Delta \mathrm{E}^{10}$.

For the series of compounds (1)-(9), the calculated $\mathrm{E}\left(\mathrm{A}^{-}\right)$, $\mathrm{E}(\mathrm{AH})$ and $\Delta \mathrm{E}$ values are given in Table 2, and a plot of $\Delta \mathrm{G}^{\mathrm{o}}$ vs. $\Delta \mathrm{E}$ is shown in Figure 1. The resulting correlation coefficient was more modest $(\mathrm{r}=0.961)$ than that obtained by Geerlings et al. ${ }^{10}$, but still quite reasonable, indicating that the deprotonation energy may be a useful descriptor for estimating the gas-phase acidity of carbon acids

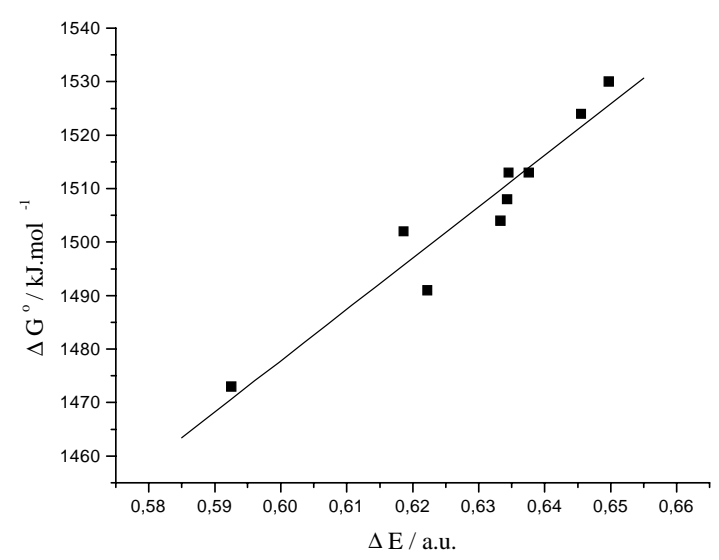

Figure 1. Correlation between gas-phase $\Delta \mathrm{G}^{\mathrm{o}}$ values and the calculated ionization energies $\Delta \mathrm{E}$ for compounds (1) - (9), calculated at the $3-21 \mathrm{G}$ level.

Table 2. Deprotonation energies of carbon acids (1) - (9), calculated from equation (7) at the 3-21G level.

\begin{tabular}{llll}
\hline & $\mathrm{Carbon} \mathrm{Acid}$ & $\mathrm{E}\left(\mathrm{A}^{-}\right)^{\mathrm{a}}$ & $\mathrm{E}(\mathrm{AH})^{\mathrm{a}}$ \\
\hline$(1)$ & $\mathrm{CH}_{3} \mathrm{NO}_{2}$ & -241.663318 & -242.255851 \\
$(2)$ & $\mathrm{CH}_{3} \mathrm{COPh}$ & -379.714997 & -380.337195 \\
$(3)$ & $\mathrm{CH}_{3} \mathrm{SO}_{2} \mathrm{Me}$ & -622.413842 & -623.032399 \\
$(4)$ & $\mathrm{CH}_{3} \mathrm{CHO}$ & -151.421949 & -152.055248 \\
$(5)$ & $\mathrm{CH}_{3} \mathrm{COEt}$ & -229.073850 & -229.708195 \\
$(6)$ & $\mathrm{CH}_{3} \mathrm{COMe}$ & -190.249607 & -190.887221 \\
$(7)$ & $\mathrm{CH}_{3} \mathrm{CO}_{2} \mathrm{Me}$ & -264.711717 & -265.346217 \\
$(8)$ & $\mathrm{CH}_{3} \mathrm{CN}$ & -130.546318 & -131.191802 \\
$(9)$ & $\mathrm{CH}_{3} \mathrm{SOMe}$ & -548.0294146 & -548.679144 \\
\hline
\end{tabular}

(a) - In atomic units 
Table 3. Global values of electronegativity $(\chi)$, hardness $(\eta)$ and softness (S) of carbon acids (1)-(9) and their corresponding anions, calculated with the 3-21G basis set.

\begin{tabular}{|c|c|c|c|c|c|c|c|}
\hline & \multicolumn{3}{|c|}{ Acids $\mathrm{CH}_{3} \mathrm{Z}$} & \multicolumn{2}{|c|}{ Anions ${ }^{-} \mathrm{CH}_{2} \mathrm{Z}$} & \multirow[b]{2}{*}{$\eta^{\mathrm{a}}$} & \multirow[b]{2}{*}{$\mathrm{S}^{\mathrm{a}}$} \\
\hline & Compounds & $\chi^{\mathrm{a}}$ & $\eta^{\mathrm{a}}$ & $\mathrm{S}^{\mathrm{a}}$ & $\chi^{\mathrm{a}}$ & & \\
\hline (1) & $\mathrm{CH}_{3} \mathrm{NO}_{2}$ & 0.168 & 0.257 & 3.891 & -0.146 & 0.240 & 4.173 \\
\hline (2) & $\mathrm{CH}_{3} \mathrm{COPh}$ & 0.129 & 0.219 & 4.574 & -0.107 & 0.175 & 5.707 \\
\hline (3) & $\mathrm{CH}_{3} \mathrm{SO}_{2} \mathrm{Me}$ & 0.107 & 0.309 & 3.239 & -0.152 & 0.264 & 3.788 \\
\hline (4) & $\mathrm{CH}_{3} \mathrm{CHO}$ & 0.127 & 0.288 & 3.467 & -0.221 & 0.262 & 3.813 \\
\hline (5) & $\mathrm{CH}_{3} \mathrm{COEt}$ & 0.115 & 0.283 & 3.534 & -0.191 & 0.243 & 4.115 \\
\hline (6) & $\mathrm{CH}_{3} \mathrm{COMe}$ & 0.118 & 0.284 & 3.521 & -0.207 & 0.252 & 3.966 \\
\hline (7) & $\mathrm{CH}_{3} \mathrm{CO}_{2} \mathrm{Me}$ & 0.121 & 0.311 & 3.212 & -0.200 & 0.257 & 3.895 \\
\hline (8) & $\mathrm{CH}_{3} \mathrm{CN}$ & 0.122 & 0.342 & 2.927 & -0.221 & 0.246 & 4.065 \\
\hline (9) & $\mathrm{CH}_{3} \mathrm{SOMe}$ & 0.082 & 0.271 & 3.694 & -0.161 & 0.241 & 4.149 \\
\hline
\end{tabular}

(a) - atomic units.

Table 3 lists the values of the global HSAB descriptors $\chi, \eta$ and $S$ calculated for acids (1)-(9) and their corresponding anions. Inspection of the Table reveals the absence of correlations between the acidity order in the gas phase of compounds (1)-(9) and the listed global descriptors. This reflects the wide variety of substituents $\mathrm{Z}$ attached to the acidic methyl group of $\mathrm{CH}_{3} \mathrm{Z}$.

Table 4 lists some local descriptors of the conjugate bases of (1)-(9). They include the charge $\mathrm{q}_{C}$ on the anionic carbon atom of $-\mathrm{CH}_{2} \mathrm{Z}$, the corresponding Fukui functions for nucleophilic attack, calculated by means of equations (4) and (6), and the local softness $\left(\mathrm{s}_{\mathrm{C}}^{-}\right)_{1}$ and $\left(\mathrm{s}_{\mathrm{C}}{ }^{-}\right)_{2}$, calculated from the corresponding Fukui functions $\left(\mathrm{f}_{\mathrm{C}}{ }^{-}\right)_{1}$ and $\left(\mathrm{f}_{\mathrm{C}}^{-}\right)_{2}$, respectively.

Table 4. Values for the charge $\left(\mathrm{q}_{\mathrm{C}}\right)$, Fukui functions for nucleophilic attack $\left[\left(\mathrm{f}_{\mathrm{C}}{ }^{-}\right)_{1}\right.$ and $\left.\left(\mathrm{f}_{\mathrm{C}^{-}}\right)_{2}\right]$, and local softness $\left[\left(\mathrm{s}_{\mathrm{C}}^{-}\right)_{1}\right.$ and $\left.\left(\mathrm{s}_{\mathrm{c}}{ }^{-}\right)_{2}\right]$ of the anionic carbon atom of $-\mathrm{CH}_{2} \mathrm{Z}$, calculated at the $3-21 \mathrm{G}$ level.

\begin{tabular}{lccccc}
\hline Conjugate Base & $\mathrm{q}_{\mathrm{C}}$ & $\left(\mathrm{f}_{\mathrm{C}}{ }^{-}\right)_{1}{ }^{\mathrm{a}}$ & $\left(\mathrm{f}_{\mathrm{C}}{ }^{-}\right)_{2}{ }^{\mathrm{b}}$ & $\left(\mathrm{s}_{\mathrm{C}}{ }^{-}\right)_{1}{ }^{\mathrm{c}}$ & $\left(\mathrm{s}_{\mathrm{c}}{ }^{-}\right)_{2}{ }^{\mathrm{d}}$ \\
\hline${ }^{-} \mathrm{CH}_{2} \mathrm{NO}_{2}$ & -0.212 & 0.197 & 0.357 & 0.822 & 1.490 \\
$-{ }^{-} \mathrm{CH}_{2} \mathrm{COPh}$ & -0.605 & 0.248 & 0.407 & 1.415 & 2.323 \\
$-{ }^{-} \mathrm{H}_{2} \mathrm{SO}_{2} \mathrm{Me}$ & -0.988 & 0.276 & 0.556 & 1.045 & 2.106 \\
$-{ }^{-} \mathrm{H}_{2} \mathrm{CHO}$ & -0.669 & 0.256 & 0.422 & 0.976 & 1.609 \\
$-{ }^{-} \mathrm{CH}_{2} \mathrm{COEt}$ & -0.627 & 0.255 & 0.424 & 1.049 & 1.745 \\
$-\mathrm{CH}_{2} \mathrm{COMe}$ & -0.636 & 0.260 & 0.424 & 1.031 & 1.682 \\
$-{ }^{-} \mathrm{CH}_{2} \mathrm{CO}_{2} \mathrm{Me}$ & -0.659 & 0.271 & 0.454 & 1.055 & 1.768 \\
$-{ }^{-} \mathrm{H}_{2} \mathrm{CN}$ & -0.632 & 0.341 & 0.494 & 1.386 & 2.008 \\
$-{ }^{-} \mathrm{CH}_{2} \mathrm{SOMe}$ & -0.882 & 0.237 & 0.544 & 0.983 & 2.257 \\
\hline
\end{tabular}

(a) calculated with equation (4); (b) calculated with equation (6); (c) calculated with equations (3) and (4); (d) calculated with equations (3) and (6).

The Mulliken charges on the anionic carbon atoms, $\mathrm{q}_{\mathrm{C}}$, do not yield a good correlation with the gas-phase acidities of compounds (1)-(9). Nevertheless, they establish clear distinctions among this heterogeneous group of carbon acids. Resonance-stabilized carbanions, where the anionic $\mathrm{C}$ atom is conjugated with one heteroatom $(\mathrm{O}$ or $\mathrm{N})$ fall into one category. Acetophenone, acetaldehyde, butanone, acetone, methyl acetate and acetonitrile all yielded $\mathrm{q}_{C}$ values in the narrow range of -
0.600 to -0.670 . The most acidic compound of the series, nitromethane, where the anionic $\mathrm{C}$ atom is conjugated with two oxygen atoms, constitutes by itself a second category, with a much smaller $\mathrm{q}_{\mathrm{C}}$ value. Finally, the dimethylsulfone and dimethylsulfoxide anions constitute the third category of conjugate bases, with the largest $\mathrm{q}_{\mathrm{C}}$ values (- 0.988 and - 0.882). Their large negative charges reflect the fact that they are in fact sulfonyl and sulfoxyl ylids. Unlike all other carbanions in the series, with a planar $\mathrm{sp}^{2}$ hybridization of the anionic $\mathrm{C}$, optimization of the conjugate bases of dimethyl-sulfone and -sulfoxide yielded $\mathrm{sp}^{3}$-type $\mathrm{C}$ atoms ${ }^{20}$.

The Fukui functions for nucleophilic attack at the anionic carbon atoms of the conjugate bases ${ }^{-} \mathrm{CH}_{2} \mathrm{Z}$ exhibited a clear trend, when compared with the gas-phase acidities of the series. Values calculated by both methods $\left[\left(\mathrm{f}_{\mathrm{C}^{-}}\right)_{1}\right.$ and $\left(\mathrm{f}_{\mathrm{C}^{-}}\right)_{2}$, from equations (4) and (6), respectively] tended to increase with the decreasing acidity of $\mathrm{CH}_{3} \mathrm{Z}$. This tendency is in agreement with the concept that a greater electronic density [equation (6)] or charge availability [equation (4)] by the anionic carbon atom of $-\mathrm{CH}_{2} \mathrm{Z}$ correspond to less delocalization, and therefore, to a decreased stability of the conjugate base. Although these qualitative trends are discernible from the data of Table 4, the correlation coefficients were not good, yielding a poor linearity in plots of $\Delta \mathrm{G}^{0}$ against $\mathrm{f}_{\mathrm{C}^{-}}$values. The poor correlations obtained $\left(\mathrm{r}=0.608\right.$ for the $\left(\mathrm{f}_{\mathrm{C}^{-}}\right)_{1}$ and 0.684 for the $\left(\mathrm{f}_{\mathrm{C}}{ }^{-}\right)_{2}$ values $)$ could be improved $(\mathrm{r}=0.882$ and 0.933 , respectively) with the elimination of the data points corresponding to dimethyl-sulfone and -sulfoxide. This again reflects the essentially different nature of the conjugate bases of these compounds, when compared with the other carbanions. Unlike the latter anions, exhibiting HOMO densities for the anionic carbon originating mainly from $\mathrm{p}_{\mathrm{z}}$ contributions, the corresponding HOMO densities for ${ }^{-} \mathrm{CH}_{2} \mathrm{SOMe}$ and $-\mathrm{CH}_{2} \mathrm{SO}_{2} \mathrm{Me}$ had significant contributions from $\mathrm{s}$ and all $\mathrm{p}$ atomic orbitals. Such differences in hybridization of ${ }^{-} \mathrm{CH}_{2} \mathrm{Z}$ led to deviations in 
the series as regards the $\mathrm{q}_{\mathrm{C}}(\mathrm{N})$ term of equation (4), and might also invalidate our assumptions of a constant and relatively negligible second term in the sum (5).

Correlations of the gas-phase acidities of compounds (1)(9) with the values of local softness $\mathrm{s}_{\mathrm{C}}$ - given in Table 4 were also poor. If the dimethyl-sulfoxide and -sulfone anions are again excluded, a general trend is observed with the $\mathrm{s}_{\mathrm{C}}{ }^{-}$values of Table 4, which tend to increase with the decreasing acidity of the compounds. Acetophenone stands out as an exception in the series, with a large $\mathrm{s}_{\mathrm{C}}{ }^{-}$and a relatively small $\Delta \mathrm{G}^{\mathrm{o}}$ value. This reflects the large global softness of the molecule and of its conjugate base, the highest $S$ value of all compounds (Table 3 ), due to the polarizable phenyl substituent. As the data of Table 1 seem to indicate, the greater acidity of acetophenone in the gas phase, when compared to that of other enolizable compounds, results from its greater polarizability. In solution, where other mechanisms of carbanion stabilization operate, there are no great differences in the acidity of the three ketones in the series.

Next, the acidity of a new carbon acid was estimated, from the properties and correlations obtained above. Methyl thioacetate (10) was an interesting choice, because of the possibility of comparing its behavior as an acid with other carbonyl compounds, both in the gas phase and in solution. Ab-initio calculations of this molecule are available in the literature ${ }^{21,22}$, the most stable conformer being the $\mathrm{Z}$, or $s y n$, form ${ }^{22}$. In contrast with the lack of data on its behaviour as an acid, comparisons have been made of its basicity with that of acetate esters, in the gas phase ${ }^{23}$ and in solution ${ }^{24}$.

Calculations perfomed with the syn conformer of methyl thioacetate, following the same protocol employed for the series (1)-(9), yielded the values for its global and local properties given in Table 5 .

Table 5. Global and local properties of methyl thioacetate (10) and its carbanion, calculated at the $3-21 \mathrm{G}$ level.

\begin{tabular}{ccc}
\hline Property & $\mathrm{CH}_{3} \mathrm{COSCH}_{3}$ & $-\mathrm{CH}_{2} \mathrm{COSCH}_{3}$ \\
\hline$\chi^{\mathrm{a}}$ & 0.108 & -0.121 \\
$\eta^{\mathrm{a}}$ & 0.259 & 0.235 \\
$\mathrm{~S}^{\mathrm{a}}$ & 3.867 & 4.250 \\
$\mathrm{q}_{\mathrm{C}}$ & - & -0.612 \\
$\left(\mathrm{f}_{\mathrm{C}}^{-}\right)_{1}$ & - & 0.163 \\
$\left(\mathrm{f}_{\mathrm{C}}^{-}\right)_{2}$ & - & 0.271 \\
$\left(\mathrm{~s}_{\mathrm{C}}^{-}\right)_{1}$ & - & 0.693 \\
$\left(\mathrm{~s}_{\mathrm{C}}\right)_{2}$ & - & 1.152 \\
\hline
\end{tabular}

(a) - In atomic units

The calculated ionization energy $\Delta \mathrm{E}$ for methyl thioacetate was equal to 0.5983 a.u. This energy is close to the value of 0.5925 a.u. obtained for nitromethane (Table 2), suggesting an acidity value $\Delta G^{0}$ for methyl thioacetate close to the reported value for $\mathrm{MeNO}_{2}$. In fact, utilizing the linear regression of Figure 1, the value of $1476 \mathrm{~kJ} \mathrm{~mol}^{-1}$ was obtained.

The high acidity of compound (10) in the gas phase is confirmed by the values of the Fukui functions for the anionic carbon of its conjugate base, $\left(f_{C^{-}}\right)_{1}=0.163$ and $\left(f_{C^{-}}\right)_{2}=0.271$. These values are again close to the corresponding values for nitromethane $(0.197$ and 0.357 , respectively), suggesting for the thioester a similar, and even higher gas-phase acidity than that for $\mathrm{CH}_{3} \mathrm{NO}_{2}$. The high acidity of methyl thioacetate, like that of acetophenone, arises from the charge-delocalization by conjugation, coupled with the great polarizability of the molecule, as a result of the presence of the soft sulfur atom. The calculated global softness of $\mathrm{MeSOCCH}_{2}^{-}, 4.250$, was larger than that for the conjugate bases of methyl acetate (3.895), acetone (3.966) or even butanone (4.115), being second only to that of the acetophenone anion (5.702).

Solvation plays a dominant role in changing the order of acidities of compounds (1)-(10) upon transfer from the gas phase to solution. One cannot expect an exact prediction of solvation effects based on the global and local descriptors listed in Tables 2-5. Nevertheless, one may look for tendencies in the solvation of these molecules by a hard solvent like water. This may provide us with a picture of the relative stability of these species in solution, and, consequently, of their relative acidity in water.

With the exception of the anions from dimethyl-sulfone and -sulfoxide, all other bases in the studied series possess a hard center $(\mathrm{O}$ or $\mathrm{N}$ ) directly conjugated with the soft anionic carbon atom. A comparison of the relative importance of these hard and soft centers in each anion may be obtained by comparing the corresponding Fukui functions $\mathrm{f}_{\mathrm{x}}{ }^{-}$of these centers in each species. The ratio $\Sigma \mathrm{f}_{\mathrm{X}}{ }^{-} / \mathrm{f}_{\mathrm{C}}{ }^{-}$, where the sum $\Sigma \mathrm{f}_{\mathrm{X}}{ }^{-}$extends over all hard centers conjugated with the anionic $\mathrm{C}$, may be utilized as a measure of the tendency of the conjugate base to be solvated by a hard solvent like water. The higher this ratio, the higher should the species be solvated by hydrogen-bonding with this solvent. In consequence, shifts in the gas-phase acidities, when compared with the $\mathrm{pK}_{\mathrm{a}}$ values in water, could be anticipated by consideration of the above ratios, which may be used as an indication of the relative stability of the carbanions in aqueous solution.

Table 6 gives the Fukui functions $\left(\mathrm{f}_{\mathrm{X}}{ }^{-}\right)_{1}$ and $\left(\mathrm{f}_{\mathrm{X}}{ }^{-}\right)_{2}$ calculated by equations (4) and (6), respectively, for the hard centers $(\mathrm{X}=\mathrm{O}$ or $\mathrm{N})$ of the anions $-\mathrm{CH}_{2} \mathrm{Z}$, exhibiting direct conjugation between the soft $\mathrm{C}$ and the hard atom(s). The corresponding ratios $\Sigma \mathrm{f}_{\mathrm{x}}-/ \mathrm{f}_{\mathrm{C}}{ }^{-}$are also given.

Inspection of the calculated values reveals a pattern of shifts of acidity from the gas-phase to aqueous solutions in agreement with the data of Table 1 . It is assumed that 
Table 6. Fukui functions, $\left(f_{X}^{-}\right)_{1}$ and $\left(f_{X}^{-}\right)_{2}$, of the hard centers $(\mathrm{X}=\mathrm{O}$ or $\mathrm{N})$ and corresponding ratios $\Sigma\left(\mathrm{f}_{\mathrm{x}}{ }^{-}\right)_{1} /\left(\mathrm{f}_{\mathrm{C}}{ }^{-}\right)_{1}$ and $\Sigma\left(\mathrm{f}_{\mathrm{x}}{ }^{-}\right)_{2} /\left(\mathrm{f}_{\mathrm{C}^{-}}\right)_{2}$ for the carbanions ${ }^{-} \mathrm{CH}_{2} \mathrm{Z}$ with direct conjugation between the soft $\mathrm{C}$ atom and the hard center. Calculations performed at the 3-21G level.

\begin{tabular}{lllll}
\hline Carbanion & $\left(\mathrm{f}_{\left.\mathrm{X}^{-}\right)_{1}}\right.$ & $\left(\mathrm{f}_{\left.\mathrm{X}^{-}\right)_{2}}\right.$ & $\begin{array}{c}\Sigma\left(\mathrm{f}_{\mathrm{x}}^{-}\right)_{1} / \\
\left(\mathrm{f}_{\left.\mathrm{C}^{-}\right)_{1}}\right.\end{array}$ & $\begin{array}{c}\Sigma\left(\mathrm{f}_{\mathrm{x}}{ }^{-}\right)_{2} / \\
\left(\mathrm{f}_{\mathrm{C}}\right)_{2}\end{array}$ \\
\hline${ }^{-} \mathrm{CH}_{2} \mathrm{NO}_{2}$ & 0.264 & 0.164 & 2.680 & 0.919 \\
$-\mathrm{CH}_{2} \mathrm{COSMe}$ & 0.121 & 0.088 & 0.742 & 0.325 \\
$-{ }^{-} \mathrm{H}_{2} \mathrm{COPh}$ & 0.337 & 0.230 & 1.359 & 0.565 \\
$-{ }^{-} \mathrm{H}_{2} \mathrm{CHO}$ & 0.368 & 0.247 & 1.437 & 0.585 \\
$-{ }^{-} \mathrm{CH}_{2} \mathrm{COEt}$ & 0.348 & 0.235 & 1.365 & 0.554 \\
$-{ }^{-} \mathrm{CH}_{2} \mathrm{COMe}$ & 0.355 & 0.236 & 1.365 & 0.557 \\
$-{ }^{-} \mathrm{CH}_{2} \mathrm{CO} \mathrm{Me}$ & 0.314 & 0.181 & 0.863 & 0.399 \\
$-{ }^{-} \mathrm{CH}_{2} \mathrm{CN}$ & 0.284 & 0.206 & 0.833 & 0.417 \\
\hline
\end{tabular}

the acidity of a carbon acid in water is roughly the result of its intrinsic acidity in the gas-phase, modulated by the aqueous solvation of its anion, and that this latter contribution is measured by the ratio $\Sigma \mathrm{f}_{\mathrm{x}}{ }^{-} / \mathrm{f}_{\mathrm{C}^{-}}$.

Methyl thioacetate and nitromethane have about the same acidity in the gas-phase. The anion of the former is, however, much less solvated by water than that of the latter (ratio values of $0.742 v s 2.680$, or $0.325 v s$. 0.919). As a result, nitromethane is much more acidic in water than methyl thioacetate, with a $\mathrm{pK}_{\mathrm{a}}$ value (10.2) about 10 units lower than that of methyl thioacetate (estimated $\mathrm{pK}_{\mathrm{a}}$ of 21.0, assumed equal to the $\mathrm{pK}_{\mathrm{a}}$ of ethyl thioacetate ${ }^{12}$ ).

Besides the usual leveling effect of the solvent, the reduced solvation by water of $-\mathrm{CH}_{2} \mathrm{COSMe}$, compared to ${ }^{-} \mathrm{CH}_{2} \mathrm{CO}_{2} \mathrm{Me}(0.742$ vs. 1.365 , or 0.325 vs. 0.399 in their ratio values), may be held responsible for the fact that the relative differences in acidity strength of the acetate and thioacetate esters are largely reduced from the gas-phase ( $\Delta \Delta \mathrm{G}^{\mathrm{o}}$ of $\mathrm{ca} .35 \mathrm{~kJ} \mathrm{~mol}^{-1}$, corresponding to a $\mathrm{pK}_{\mathrm{a}}$ difference of about 33 units) to aqueous solutions ( $\Delta \mathrm{pK}_{\mathrm{a}}$ of $c a .4$ units).

The values in Table 6 also show that the ketone enolates are all similarly solvated in water, and better so than the acetate enolate (ratios of $1.4 \mathrm{vs}$. 0.86 , or $0.56 \mathrm{vs}$. 0.40 ). Thus, although methyl acetate and acetone have the same acidity in the gas-phase (Table 1), the latter becomes a stronger acid than the former in water $\left(\mathrm{pK}_{\mathrm{a}}\right.$ values of 19.3 and 25.6, respectively).

Finally, the low intrinsic acidity of acetonitrile in the gas-phase, coupled with its poor solvation in water (ratio values of 0.833 , or 0.417 , comparable to those of the acetate and thioacetate esters), makes this compound one of the least acidic in the series of compounds of Table 6 .

The above analysis and the choices made in this paper are open to criticism. Firstly, free-energy values $\Delta \mathrm{G}^{\mathrm{o}}$ were correlated with the calculated deprotonation energies $\Delta \mathrm{E}$, neglecting all entropic contributions to the gas-phase acidity of compounds (1)-(10). This may be justified by the good linear relationship between the experimental $\Delta \mathrm{G}^{\mathrm{o}}$ and $\Delta \mathrm{H}^{\mathrm{o}}$ values for the set of studied compounds, with a correlation coefficient of $0.999^{16}$. The theoretical deprotonation energies $\Delta \mathrm{E}$, which measure enthalpic variations only, may thus be compared with the experimental free-energy values $\Delta \mathrm{G}^{\mathrm{o}}$, since the entropic contribution to the gas-phase acidity is practically constant for all compounds in the series.

A second point may be raised, regarding the low level of theory employed in the present work. The choice of the 3$21 \mathrm{G}$ basis set was determined by our intention of comparing the set of carbon acids with studies on other compounds reported in the literature under the same conditions. A possible improvement in this approach, with minimum additional cost, might be the use of polarization or diffuse functions for singlepoint calculations of structures optimized at a lower level of theory. This should be especially convenient when dealing with the anionic conjugate bases of carbon acids $\mathrm{CH}_{3} \mathrm{Z}$, since diffuse functions are normally employed for calculations involving anionic species.

We therefore decided to follow this protocol for all studied compounds, optimizing all $\mathrm{CH}_{3} \mathrm{Z}$ and ${ }^{-\mathrm{CH}_{2}} \mathrm{Z}$ structures at the 3-21G level, and carrying out single-point calculations with the $6-31 \mathrm{G}^{*}$ and the $6-31+\mathrm{G}(3 \mathrm{df}, 2 \mathrm{p})$ basis sets. These calculations were restricted to the $\Delta \mathrm{E}$ and $\left(\mathrm{f}_{\mathrm{C}}{ }^{-}\right)_{2}$ descriptors, which had yielded the best correlations with the experimental gas-phase acidities of compounds (1)-(9). The obtained results are given in Table 7. It can be seen that this supposedly improved approach reproduces the trends obtained with the 3-21G method. Gas-phase acidities increase with the calculated deprotonation energies $\Delta \mathrm{E}$, with correlation coefficients of 0.915 , for the $6-31 G^{*} / / 3-21 \mathrm{G}$ method, and of 0.870 for the $6-31+\mathrm{G}(3 \mathrm{df}, 2 \mathrm{p}) / / 3-21 \mathrm{G}$ method. Both values correspond to worse correlations than that of 0.961 obtained with the $3-21 \mathrm{G}$ basis set. According to the calculated deprotonation energies of methyl thioacetate, compound (10) should be one of the most acidic member of the series, with an acidity comparable to that of nitromethane. The gas-phase acidity is also seen to increase with the nucleophilic Fukui function values $\left(\mathrm{f}_{\mathrm{C}}{ }^{-}\right)_{2}$ of the anionic carbon atom of ${ }^{-} \mathrm{CH}_{2} \mathrm{Z}$, according to both methods. As observed with the calculations at the 3-21G level, the obtained correlations were rather poor $(r=0.689$ for the 6 $31 \mathrm{G}^{*} / / 3-21 \mathrm{G}$, and $\mathrm{r}=0.680$ for the $6-31+\mathrm{G}(3 \mathrm{df}, 2 \mathrm{p}) / / 3-$ $21 \mathrm{G}$ method), and could be improved to $\mathrm{r}=0.949$ and $\mathrm{r}=$ 0.957, respectively, when the data points for dimethylsulfoxide and -sulfone were omitted from the plots. Again, the use of polarization or diffuse functions represented little, if any improvement over the 3-21G method, which yielded coefficients $r$ equal to 0.684 and 0.933 respectively. This observation is in line with previous studies which suggested that the use of larger basis sets does not necessarily lead to better correlations with experimental acidities or basicities ${ }^{5}$. 
Table 7. Nucleophilic Fukui functions $\left(\mathrm{f}_{\mathrm{C}}^{-}\right)_{2}$ and deprotonation energies $\Delta \mathrm{E}$, calculated with a 6-31G* // 3-21G and with a 6-31+G(3df,2p) // 3-21G method for compounds (1)-(10) and their conjugate bases.

\begin{tabular}{|c|c|c|c|c|c|c|}
\hline & Compound & $\Delta \mathrm{G}^{\mathrm{o}}, \mathrm{kJ} . \mathrm{mol}^{-1}$ & $\left(f_{C^{-}}\right)_{2}{ }^{a}$ & $\left(\mathrm{f}_{\mathrm{C}^{-}}\right)_{2}{ }^{\mathrm{b}}$ & $\Delta \mathrm{E}$, a.u. $^{\mathrm{a}}$ & $\Delta \mathrm{E}$, a.u. $^{\mathrm{b}}$ \\
\hline (1) & $\mathrm{CH}_{3} \mathrm{NO}_{2}$ & 1473 & 0.315 & 0.268 & 0.6100 & 0.5962 \\
\hline (2) & $\mathrm{CH}_{3} \mathrm{COPh}$ & 1491 & 0.372 & 0.321 & 0.6239 & 0.6091 \\
\hline (3) & $\mathrm{CH}_{3} \mathrm{SO}_{2} \mathrm{Me}$ & 1502 & 0.502 & 0.477 & 0.6165 & 0.5993 \\
\hline (4) & $\mathrm{CH}_{3} \mathrm{CHO}$ & 1504 & 0.384 & 0.324 & 0.6317 & 0.6107 \\
\hline (5) & $\mathrm{CH}_{3} \mathrm{COEt}$ & 1508 & 0.386 & 0.342 & 0.6345 & 0.6178 \\
\hline (6) & $\mathrm{CH}_{3} \mathrm{COMe}$ & 1513 & 0.391 & 0.342 & 0.6356 & 0.6151 \\
\hline (7) & $\mathrm{CH}_{3} \mathrm{CO}_{2} \mathrm{Me}$ & 1513 & 0.418 & 0.362 & 0.6391 & 0.6228 \\
\hline (8) & $\mathrm{CH}_{3} \mathrm{CN}$ & 1524 & 0.452 & 0.395 & 0.6410 & 0.6199 \\
\hline (9) & $\mathrm{CH}_{3} \mathrm{SOMe}$ & 1530 & 0.462 & 0.496 & 0.6440 & 0.6336 \\
\hline (10) & $\mathrm{CH}_{3} \mathrm{COSMe}$ & - & 0.238 & 0.204 & 0.6228 & 0.6138 \\
\hline
\end{tabular}

(a) Calculated by the 6-31G* // 3-21G method; (b) calculated by the 6-31+G(3df,2p) // 3-21G method.

In conclusion, the present paper investigated the existence of correlations between the gas-phase acidities of nine carbon acids of the form $\mathrm{CH}_{3} \mathrm{Z}$ and global and local properties of these molecules, calculated with a 3-21G basis set, based on the HSAB principles. A reasonably good correlation $(\mathrm{r}=$ 0.961 ) was obtained between literature $\Delta G^{0}$ values and the calculated ionization energies of all compounds. No correlations were observed between global HSAB properties of the acids or their anions and the $\Delta \mathrm{G}^{\mathrm{o}}$ values, probably because of the heterogeneity of the studied series. Local descriptors reflected the nature of the carbanion, establishing a distinction between $-\mathrm{CH}_{2} \mathrm{Z}$ which presented direct conjugation between the carbanionic center and an oxygen or nitrogen atom, and the pair dimethyl-sulfone/-sulfoxide, where this conjugation was absent. The Fukui function for nucleophilic attack of the anionic carbon atom of $-\mathrm{CH}_{2} \mathrm{Z}$, calculated following two different approaches, yielded reasonable correlations with the gas-phase acidities of the former compounds. For this series of acids, the strength of the conjugate bases increased with the value of the nucleophilic Fukui function at the carbon atom. The obtained correlation between $\Delta \mathrm{G}^{\mathrm{o}}$ and the calculated ionization energies was used to estimate the acidity of methyl thioacetate in the gas phase. The result indicated that this compound should have nearly the same intrinsic acidity as nitromethane. The shifts from gas-phase to aqueous acidities of the studied compounds, where direct conjugation between a soft carbon atom and hard $\mathrm{O}$ or $\mathrm{N}$ atoms exist in the anions, were interpreted in terms of the ratios of the nucleophilic Fukui functions between the hard centers and the soft $\mathrm{C}$ atom.

The use of larger basis sets and polarization $\left(6-31 \mathrm{G}^{*}\right)$ or diffuse functions $(6-31+\mathrm{G}(3 \mathrm{df}, 2 \mathrm{p}))$ for single-point calculations of deprotonation energies and nucleophilic Fukui functions for the anionic carbon atoms reproduced the trends observed with the $3-21 \mathrm{G}$ method, but did not improve the correlations between the theoretical descriptors with the experimental gas-phase acidities.

\section{Acknowledgements}

Financial support from USACH-DICYT is acknowledged.

\section{References}

1. Parr, R. G.; Pearson, R. G. J. Am. Chem. Soc. 1983, 105, 7512.

2. Pearson, R. G. J. Am. Chem. Soc. 1985, 107, 6801.

3. Pearson, R. G. J. Chem. Educ. 1987, 64, 561.

4. Yang, W.; Mortier, W. J. J. Am. Chem. Soc. 1986, 108, 5708.

5. Contreras, R. R.; Fuentealba, P.; Galván, M.; Pérez, P. Chem. Phys. Lett. 1999, 304, 405.

6. De Proft, F.; Langenaeker, W.; Geerlings, P. J. Phys. Chem. 1993, 97, 1826.

7. De Proft, F.; Langenaeker W.; Geerlings, P. Tetrahedron, 1995, 51, 4021.

8. De Proft, F.; Amira, S.; Choho, K.; Geerlings, P. J. Phys. Chem. 1994, 98, 5227.

9. Méndez, F.; Romero, M.L.; De Proft, F.; Geerlings, P. J. Org. Chem. 1998, 63, 5774.

10. Choho, K.; Van Lier, G.; Van de Woude, G.; Geerlings, P. J. Chem. Soc. Perkin 2, 1996, 1723.

11. Hawkinson, D. C.; Feiock, J. M.; Nevy, J. B.; Wu, Y.Zh. J. Org. Chem. 1998, 63, 5345.

12. Amyes, T. L.; Richard, J. P. J. Am. Chem. Soc. 1996, $118,3129$.

13. Amyes, T. L.; Richard, J. P. J. Am. Chem. Soc. 1992, 114, 10297.

14. Gaussian 94, Frisch, M. J.; Trucks, G. W.; Schlegel, W. B.; Gill, P. M. W.; Johnson, B. G.; Robb, M. A.; Cheeseman, J. R.; Keith, T. A.; Peterson, G. A.; Montgomery, J. A.; Raghavachari, K.; Al-Laham, M. A.; Zahrzewski, V. G.; Ortiz, J. V.; Foresman, J. B.; Cioslowski, J.; Stefanov, B. B.; Nanayakkara, A.; Challecombe, M.; Peng, C. Y.; Ayala, P. Y.; Chen, W.; 
Wong, M. W.; Andres, J. L.; Replogle, E. S.; Gomperts, R.; Martin, R. L.; Fox, D. J.; Binkley, J. S.; Defrees, D. J.; Baker, J.; Stewart, J. P.; Head-Gordon, M.; Gonzalez, C.; Pople, J. A.; Gaussian Inc., Pittsburgh, PA, 1995.

15. Houk, K.N.; Wang, X. J. Am. Chem. Soc. 1988, 110, 1870.

16. Isaacs, N. S. Physical Organic Chemistry, Longman, Essex, England, 1992.

17. Bordwell, F. G. Acc. Chem. Res. 1988, 21, 456.

18. Bordwell, F. G.; Taft, R.W. Acc. Chem. Res. 1988, 21, 463.

19. Bordwell, F. G.; Fried, H. E.; Hughes, D. L.; Lynch, T. Y.; Satish, A. V.; Whang, Y. E. J. Org. Chem. 1990, 55,3330 .

20. It is interesting to note that these corresponded to the $a b$ initio-optimized structures. The preliminarily AM1optimized structures of dimethyl-sulfoxide and -sulfone anions yielded planar, $\mathrm{sp}^{2}$-type anionic $\mathrm{C}$ atoms. These simple examples caution against the use of AM1-optimized structures for single-point calculations of HSAB parameters at a higher level of theory. Though justified in terms of computational costs (as, for example, in ref. 10), this procedure may lead to significant distortions.

21. Jones, D.; Modelli, B.; Olivato, P. R.; Dal Colle, M.; De Palo, M.; Distefano, G. J. Chem. Soc. Perkin Trans. 2, 1994, 1651.

22. Deerfield, D. W. II; Pedersen, L.G., THEOCHEM 1995, 358, 99.

23. Grunwell, J. R.; Foerst, D. L.; Kaplan, F.; Siddigui, J. Tetrahedron, 1977, 33, 2781.

24. (a) Smolders, A.; Maes, G.; Zeegers-Huyskens, T. J. Mol. Struct. 1988, 172, 23. (b) Maes, G.; Smolders, A.; Vandevyvere, P.; Vanderheyden, L.; ZeegersHuyskens, T. J. Mol. Struct. 1988, 173, 349.

Received: November 19, 1999 Published on the web: October 13, 2000 